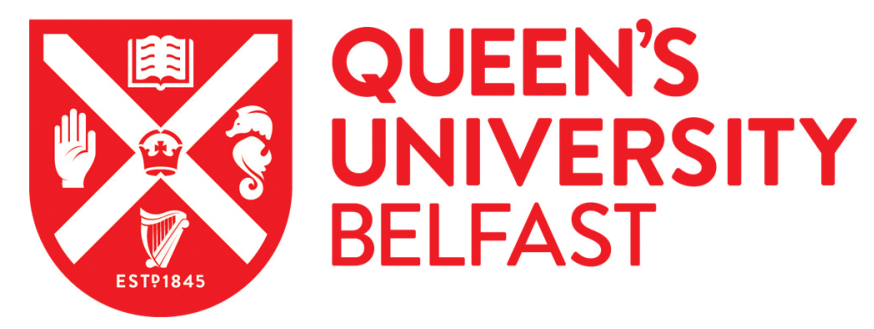

\title{
Characterization and dissolution properties of phytolith occluded phosphorus in rice straw
}

Trinh, T. K., Nguyen, T. T. H., Nguyen, T. N., Wu, T. Y., Meharg, A. A., \& Nguyen, M. N. (2017). Characterization and dissolution properties of phytolith occluded phosphorus in rice straw. Soil and Tillage Research, 171, 19-24. https://doi.org/10.1016/j.still.2017.04.002, https://doi.org/10.1016/j.still.2017.04.002

\section{Published in:}

Soil and Tillage Research

\section{Document Version:}

Peer reviewed version

Queen's University Belfast - Research Portal:

Link to publication record in Queen's University Belfast Research Portal

\section{Publisher rights}

(c) 2017 Elsevier Ltd. This manuscript version is made available under the CC-BY-NC-ND 4.0 license http://creativecommons.org/licenses/by$\mathrm{nc}-\mathrm{nd} / 4.0 /$,which permits distribution and reproduction for non-commercial purposes, provided the author and source are cited.

\section{General rights}

Copyright for the publications made accessible via the Queen's University Belfast Research Portal is retained by the author(s) and / or other copyright owners and it is a condition of accessing these publications that users recognise and abide by the legal requirements associated with these rights.

Take down policy

The Research Portal is Queen's institutional repository that provides access to Queen's research output. Every effort has been made to ensure that content in the Research Portal does not infringe any person's rights, or applicable UK laws. If you discover content in the Research Portal that you believe breaches copyright or violates any law, please contact openaccess@qub.ac.uk. 
$5{ }^{1}$ Faculty of Environmental Science, VNU University of Science, Vietnam National 6 University, Hanoi (VNU), 334 Nguyen Trai, Thanh Xuan, Hanoi, Viet Nam.

$7 \quad 2$ Institute for Nuclear Science and Technology, 179 Hoang Quoc Viet, Hanoi, Viet Nam.

$8{ }^{3}$ Faculty of Environment, Vietnam National University of Agriculture, Trau Quy, Gia Lam, 9 Hanoi, Viet Nam.

$10{ }^{4}$ Chemical Engineering Discipline, School of Engineering, Monash University, Jalan Lagoon 11 Selatan, 47500 Bandar Sunway, Selangor Darul Ehsan, Malaysia.

$12{ }^{5}$ Institute for Global Food Security, Queen’s University Belfast, David Keir Building, 13 Malone Road, BT9 5BN, Northern Ireland, UK.

14 * Correspondence: Dr. Minh N. Nguyen, E-mail: minhnn@vnu.edu.vn

\section{Characterization and dissolution properties of phytolith occluded}

\section{phosphorus in rice straw}

Trang K. Trinh ${ }^{1}$, Thinh T. H. Nguyen ${ }^{2}$, Tu N. Nguyen ${ }^{3}$, Ta Yeong $\mathrm{Wu}^{4}$, Andrew A. Meharg ${ }^{5}$, Minh N. Nguyen*1, 5
16

17

\section{Introduction}

Rice straw derived phytolith, a silicaceous structure formed through Si precipitation in rice plant tissues (Parr and Sullivan, 2005), has been widely known as a potential source to sustain soil Si nutrient pools when it is cycled to soils (Dobermann and Fairhurst, 2000; Nguyen et al., 2014; Nguyen et al., 2015; Seyfferth et al., 2013). However, there has been a lack of systematic information on the fate of rice straw derived phytolith in soils, and to what extent this nutrient pool can benefit crops. Phosphorus (P) is among the most important nutrient elements in rice. $\mathrm{P}$ is taken up from the soil solution by root absorption, transport across cell membranes and compartmentation, and redistribute within different parts of rice plant (Agarie et al., 1996; Schachtman et al., 1998; Yamaji et al., 2008). During rice growth, 
P can be re-translocated through rice’s xylem/phloem system (Schachtman et al., 1998), and some parts might be trapped within phytolith structure (so-called phytOP) when Si precipitates. This means that even if rice straw is cycled to soil, this $\mathrm{P}$ pool might still exist inside phytolith and unavailable for plant uptakes. There has been a knowledge gap and lack of experimental evidence for the fate of phytOP and its capacity to serve as an additional $\mathrm{P}$ source for crops.

Generally, dissolution of phytolith is regulated by the desilification in aqueous solution. This process occurs via hydrolysis of $\equiv \mathrm{Si}-\mathrm{O}-\mathrm{Si} \equiv$ bonds of the silica surface in which water molecules orient their electronegative pole towards the Si atoms in silica structure, resulting in a transfer of electron density to the $\equiv \mathrm{Si}-\mathrm{O}-\mathrm{Si} \equiv$ bonds, thereby raising their length and consequently breaking them (Dove and Crerar, 1990). $\mathrm{pH}$ is well understood as a crucial factor driving phytolith dissolution kinetics via protonation or deprotonation reactions (Fraysse et al., 2009; Nguyen et al., 2014) which can either increase resistance of the surface or make the surface more vulnerable from nucleophilic attacks (Dove and Crerar, 1990). On the other hand, occluded organic matter can be another factor in preserving phytolith since it may act as a protective shield against hydrolysis of the silica (Nguyen et al., 2014; Parr and Sullivan, 2005). In this study, the release of $\mathrm{P}$ was inspected in considering the dissolution rate of phytolith’s silica body and influence of occluded organic matter content. of straw to return nutrients to the soils in many rice-based countries. Although this method causes significant emission of greenhouse gases (e.g. $\mathrm{CO}_{2}, \mathrm{CO}, \mathrm{NO}_{\mathrm{x}}$ ), losses of nutrients (e.g. N, K, P,) and contributes to air pollution (Andreae and Merlet, 2001; Bijay et al., 2008; Dobermann and Fairhurst, 2000), it is the easiest way of returning most nutrients to the soils, and at present rice growers have little incentive to change this method. As burning of rice straw at different temperatures might result in various degrees of dehydroxylation of biogenic 
51 silica and organic matter contents, rice straw phytolith ash samples which were obtained from

52300 to $1000^{\circ} \mathrm{C}$ ashing temperatures were used to examine the release of $\mathrm{P}$ in batch experiments. X-ray tomographic microscopy (Marone, 2010), provided a visualization for silicaceous structure of phytolith. Scanning electron microscopy (SEM), X-ray diffraction (XRD), Fourier transform infrared spectroscopy (FTIR), specific surface area (SSA) and chemical composition analysis were carried out to evaluate transformation of phytolith and its effect on P release. Statistical analysis using Pearson's test can help to provide an additional information of correlation between the released $\mathrm{Si}$ and $\mathrm{P}$. Based on the identification of relation between the release of $\mathrm{P}$ and dissolution of rice-straw phytolith, this study clarifies the dynamics of the phytOP and suggest possible management options on one hand to maximize the use of this phytOP pool, and on the other hand to adjust fertilization strategy.

\section{Materials and Methods}

\section{2.1. Study site and sample production}

River Delta (RRD), a second largest delta in Vietnam. In the RRD, approx. 12 tons $\mathrm{ha}^{-1}$ of the rice straw can be annually burnt and returned to the fields which serves as large amount of phytolith for paddy soils. The rice-straw was air-dried, milled and passed through a $1.0-\mathrm{mm}$ sieve. Ashing was conducted by heating the rice straw sample in an furnace at a target temperature range between 300 and $1000^{\circ} \mathrm{C}$ for $2 \mathrm{~h}$. The derived phytolith containing ash was washed with DI water, followed by centrifugation and decantation, and finally were dried at $60^{\circ} \mathrm{C}$ in an oven for $24 \mathrm{~h}$. The samples from pretreatments at $300,400,500,600,700,800$, 900 and $1000^{\circ} \mathrm{C}$ were used for chemical analysis, mineralogical characterizations, SSA analysis and batch dissolution experiments. For kinetic experiments, the samples treated at 400, 700 and $1000^{\circ} \mathrm{C}$ were selected.

\subsection{Sample characterization}


Tomographic and morphological analysis: a 3D image of the silicaceous structures of a rice plant was built by using YaDiV software (Friese et al., 2013), and input data from X-ray tomographic microscopy by TOMCAT (TOmographic Microscopy and Coherent rAdiology experimenTs) beamline at the Swiss Light Source, Paul Scherrer Institute, Villigen, Switzerland. Dry rice leaf was scanned under monochromatic beam from a $2.9 \mathrm{~T}$ superbending magnet at an energy of $11.1 \mathrm{keV}$. Micromorphology of the sample was inspected by using SEM (FEI Quanta 600 FEG, USA).

Chemical composition: To examine chemical composition, the samples derived from pretreatments at 300 to $1000^{\circ} \mathrm{C}$ were examined using the Particle Induced X-Ray Emission (5SDH-2 Pelletron accelerator system, USA). Total organic carbon (TOC) in the samples was measured by wet digestion with concentrated $\mathrm{H}_{2} \mathrm{SO}_{4}$ and $0.5 \mathrm{M} \mathrm{K}_{2} \mathrm{Cr}_{2} \mathrm{O}_{7}$ at $170-180{ }^{\circ} \mathrm{C}$. $X$-ray diffraction, FTIR and surface area analysis: Silica phases of the ash samples were examined by powder X-ray diffraction (Bruker AXS D5005, Germany). The surface groups of the ash samples were identified by using FTIR measurements (Nicolet ${ }^{\mathrm{TM}}$ iS $^{\mathrm{TM}} 5$ FT-IR, Thermo Scientific, USA). The SSA of the samples was measured with a Gemini VII 2390p surface area analyzer.

\subsection{Kinetic batch experiments}

To examine P and Si solubility, $300 \mathrm{mg}$ of sample was mixed with $300 \mathrm{~mL}$ of DI water in 500-mL plastic tubes. Suspensions were gently shaken and allowed to stand for $24 \mathrm{~h}$ at room temperature. For the samples pre-treated at 400,700 and $1000^{\circ} \mathrm{C}$, the batch experiments were in triplicates and extended up to $6 \mathrm{~d}$ with sampling at $24 \mathrm{~h}$ intervals. The suspensions were passed through a $0.45 \mu \mathrm{m}$ filter paper. Soluble P was determined using ion chromatography (DX-600, Dionex-Thermo, USA) while soluble Si was examined by molybdate blue method with a Spectrophotometer UV-Vis (L-VIS-400, Labnics, USA). Since

100 the ash samples still contain certain amounts of OC, dissolution of the OC might affect 
101 releases of Si and P by changing phytolith exposure to solution. In all kinetic experiments,

102 DOC was also analysed using a TOC Analyzer (VCPH, Shimadzu), to identify whether the 103 released P was related to dissolution of occluded organic matter. Correlations between the 104 released Si and P derived from all dissolution kinetic experiments were also evaluated by

105 Pearson's test using SPSS 20.0 software program. The strength of correlation can be 106 evaluated by using two levels of significance 0.01 and 0.05 , representing relations between 107 the released Si and P occurring by chance are 1 and 5\%, respectively.

\section{3. Results}

\subsection{Sample characterization}

The arrangement of phytolith's silicaceous structure in the rice leaf was visualized in

111 Fig. 1. A high-porosity system with various size holes which might represent longitudinal

112 vascular bundles, veins or fibers of the rice plant (Botha, 2013). Si covers, throughout, 113 internal- and external surfaces of the vascular system to form a coating layer, coloured

114 yellow, as shown in Fig. 1a. This layer is known as silica-rich epidermis which is developed 115 to become the main strengthening tissue in the stem and leaf (Islam et al., 2009; Yamanaka et 116 al., 2009). The holes can be fulfilled by organic matter which appears in violet (Fig. 1b).

117 Excessive precipitation of Si can likely to form "closed holes" within the vascular bundles, 118 capturing embedded organic matter, as well other occluded substances including P.

119 (Figure 1)

120 Heat treatments of the rice straw resulted in significant changes in chemical 121 composition and SSA as shown in Tab. 1. The organic carbon was almost completely 122 removed by heating at $>800{ }^{\circ} \mathrm{C}$, whereas, only less than $30 \%$ of TOC was removed at $300{ }^{\circ} \mathrm{C}$.

123 In rice straw the total $\mathrm{P}$ and $\mathrm{Si}$ contents were 1.02 and $73.6 \mathrm{~g} \mathrm{~kg}^{-1}$, respectively. However, the 124 contents of P changed from 1.21 to $2.55 \mathrm{~g} \mathrm{~kg}^{-1}$ and those of Si varied from 87.6 to $184.2 \mathrm{~g} \mathrm{~kg}^{-}$ 125 , when the heating temperatures of rice straw increased from 300 to $1000^{\circ} \mathrm{C}$. A severe 
126 decrease of the SSA was obtained with increasing heating temperature. The SSA decreased

127 from 36.2 to $0.22 \mathrm{~m}^{2} \mathrm{~g}^{-1}$ with an increase of heating temperature from 300 to $1000^{\circ} \mathrm{C}$,

128 indicating an enhanced condensation of silica structures at higher temperatures as shown in

129 Fig. 2.

130 (Table 1)

131 (Figure 2)

132 The XRD for phytolith derived from different treatment temperatures is shown in Fig.

133 3a. At temperatures $<700^{\circ} \mathrm{C}$, no specific reflection was observed, suggesting that silica

134 occurs in amorphous form. Temperatures $>800^{\circ} \mathrm{C}$ can favor crystalization and cause the

135 formation of more stable silica crystaline structures, i.e., cristobalite and trydimite (Kordatos

136 et al., 2008). Functional groups of the samples were revealed through FTIR spectra as

137 described in Fig. 3b. The bands at $\sim 1100 \mathrm{~cm}^{-1}$ and $800 \mathrm{~cm}^{-1}$, representing for the stretching

138 vibration of the $\mathrm{SiO}_{4}$ tetrahedron and the bending vibration of inter-tetrahedral $\equiv \mathrm{Si}$-O-Si=

139 bonds, were apparent for almost all pretreatments.

140 (Figure 3)

$141 \quad 3.2$. Solubility of Si and $P$

142 Dissolution kinetics

143 Batch experiments for the samples derived from different heat-treatments showed that

144 the concentration of soluble P and Si significantly increased with time at different rates for

145400 and $700^{\circ} \mathrm{C}$-treated samples, whereas trivial increases of soluble P and Si were observed

146 for $1000^{\circ} \mathrm{C}$-treated sample (Fig. 4a, b). After $6 \mathrm{~d}$, P and Si releases were 1.2 and $41.0 \mathrm{mg} \mathrm{L}^{-1}$

147 for the $400^{\circ} \mathrm{C}$ treated sample, 2.0 and $55.0 \mathrm{mg} \mathrm{L}^{-1}$ for the $700^{\circ} \mathrm{C}$-treated sample, and 0.04 and

$1483.3 \mathrm{mg} \mathrm{L}^{-1}$ for the $1000^{\circ} \mathrm{C}$-treated sample, respectively. For 400 and $700^{\circ} \mathrm{C}$-treated samples,

149 P concentration showed a remarkable increase within the first day, and minor increases after 
150 day 1 while Si concentration in the supernatant continuously increased over $6 \mathrm{~d}$. The releases 151 of DOM in batch experiments were also examined, but no clear trend has been observed.

152 (Figure 4) $700^{\circ} \mathrm{C}$ were 0.968 and 0.878 (respectively), indicating a relation between released Si and P. In contrary, a correlation coefficient of -0.504 implies that no clear relation exists between released Si and $\mathrm{P}$ for the sample treated at $1000^{\circ} \mathrm{C}$. For the samples treated at 400 and $700^{\circ} \mathrm{C}$,

157 a significant correlation at the 0.01 level is an obvious evidence for a strong relation between

158 Si and P, suggesting that release of P relates to the dissolution of phytolith. For the sample treated at $1000^{\circ} \mathrm{C}$, the relation between released Si and P cannot be affirmed due to a very low solubility of phytolith. A normalized correlation coefficient of 0.922 was obtained when Pearson's test was executed for all the samples together, and this correlation showed a

162 significance at 0.01 level.

163 Effect of treatment temperature

The solubility of P and Si of the phytolith samples showed a strong dependence on heating temperature (Fig. 5). When the heating temperature was changed from 300 to $600^{\circ} \mathrm{C}$, increases of the soluble $\mathrm{P}$ and Si from 0.4 to $1.3 \mathrm{mg} \mathrm{L}^{-1}$ and 7.2 to $13.5 \mathrm{mg} \mathrm{L}^{-1}$, respectively,

167 were observed. At $>700^{\circ} \mathrm{C}$, the solubility of $\mathrm{P}$ and $\mathrm{Si}$ was readily reduced. The lowest values 168 of soluble P and Si were 0.04 and $0.27 \mathrm{mg} \mathrm{L}^{-1}$ (respectively) for the sample treated at $1000^{\circ} \mathrm{C}$.

169 Over the entire range of heating temperature from 300 to $1000^{\circ} \mathrm{C}, \mathrm{P}$ showed a relatively lower solubility as compared to Si. It can be recognized that soluble P and Si showed similar "peak

171 shape” trends as depicted in Fig. 5, and the highest values were at $\sim 600^{\circ} \mathrm{C}$. This phenomenon 172 suggested that a similar mechanism drove the dissolution of $\mathrm{P}$ and Si from the samples.

173 (Figure 5)

\section{4. Discussion}


Si and P assimilated from soil are transferred to rice leaf and stem. While Si tends to

176 be immobilized by precipitation that forms silicaceous phytolith structure (Nguyen et al., 177 2014; Parr and Sullivan, 2005), it is likely that P is more mobile in plant. P stored in older 178 leaves can be readily re-translocated to both young leaves and growing roots via the xylem 179 and phloem systems (Jeschke et al., 1997). X-ray tomographic microscopy revealed various 180 holes within the phytolith and these holes were filled with occluded organic substances (Fig. 181 1). However, these holes as well as morphology of the phytolith can be strongly affected by heat-treatment as shown in Fig. 2, in which high treatment temperatures resulted in a rearrangement and followed by crystallization of silica in phytolith structure as deduced from XRD spectra in Fig. 3a. As $\mathrm{P}$ is dominant in the transport sap (Schachtman et al., 1998), P and organic compounds might also be trapped inside silicaceous structure of phytolith when precipitation of Si forms phytolith. Chemical analysis revealed that phytOP contents of the samples obtained from various treatment temperatures were up to $2.55 \mathrm{~g} \mathrm{~kg}^{-1}$.

Six-day extractions of the samples treated at 400 and $700^{\circ} \mathrm{C}$ resulted in $\mathrm{Si}$ concentrations of 41 and $55 \mathrm{mg} \mathrm{L}^{-1}$, respectively, which were both equivalent to $31 \%$ of the

190 total $\mathrm{Si}$ introduced in the experiment. This result is in between the findings of 191 Wickramasinghe and Rowell (2006), Nguyen et al. (2014) and Wilding et al. (1979), who measured a Si extractability of $20-38 \%, 46 \%$ and $50-75 \%$, respectively. It can be inferred that burning process resulted in robust destruction of the rice straw and produced a structure with

194 low resistance to dissolution. In contrast, soluble amount of the sample treated at $1000^{\circ} \mathrm{C}$ was 195 less than $2 \%$ indicating its high resistance against dissolution. This implies that burning rice 196 straw at high temperatures $\left(>800^{\circ} \mathrm{C}\right)$ can lead to a long-term stabilization of rice straw phytoliths under actual soil conditions. 
suggested a relationship between the released Si and P. Scatter plots as shown in Fig. 6 demonstrate a strong correlation between the released $\mathrm{Si}$ and $\mathrm{P}$ amounts. A positive correlation, $\mathrm{R}^{2}=0.847$, indicates $\sim 85 \%$ of the variance in the soluble $\mathrm{P}$ is related to soluble Si. Also, strong correlation coefficients at the 0.01 level obtained from Pearson's test allow generalizing a relation between $\mathrm{P}$ and $\mathrm{Si}$, in which the $\mathrm{P}$ release is regulated by the dissolution of the phytolith and treatment temperature appears as a primary factor driving this process.

206 (Figure 6)

Changes in the removal rate of occluded organic matter and transformation of the silica phases during the heating were recognized as two of the major factors directing Si and P release from rice straw phytoliths. High organic matter content in the samples heated at low

210 temperature is likely a major factor to inhibit Si and P liberates. It might be because the

211 heating treatments resulted in an inter-embedded organic-silica structure and this matter acts as a "two-surface shield", by which each of organic matter and phytolith silica can be

213 preserved from the other. As a consequence, the presence of occluded organic matter can

214 decrease of dissolution rate of the phytolith and phytOP as well. The present result is in 215 agreement with other findings (Nguyen et al., 2014; Parr and Sullivan, 2005) in which it was 216 stated that occluded organic matter "strengthens" the phytolith surface and its resistance to 217 desilification. When heating temperature increases, dehydroxylation of silanol groups will 218 favor a formation of siloxane bonds (Fig. 2a), and the surface is hydrophobic (Zhuravlev, 219 2000). This reaction diminishes adsorption of water molecules on the surface and decreases 220 the breakage of the surface $\equiv \mathrm{Si}-\mathrm{O}-\mathrm{Si} \equiv$ bonds (Parr and Sullivan, 2005). It can, therefore, explain why lesser Si and P were liberated from the phytoliths in this case. Additionally, the formation of stable silica phases at high temperature favored a product with low SSA and less 223 activity (Kordatos et al., 2008), likely also resulting in a decline of P and Si release. An 224 illustration for the effects of occluded organic matter, SSA and crystalization degree together 
on co-release of Si and P was depecited in Fig. 7. Burning rice straw at a temperature range

226 from 500 to $700^{\circ} \mathrm{C}$ was suggested as an optimal practice toward serving more available Si and

227 P for soils and crops.

228 (Figure 7)

229

\section{Conclusions}

Rice straw phytoliths contain up to $2.5 \mathrm{~g} \mathrm{P} \mathrm{kg}^{-1}$, indicating that this $\mathrm{P}$-pool can be an additional source for crops when the straw is returned to the soils. By integrating the results from batch experiments, chemical analysis, and X-ray tomographic microscopy, this study revealed that $\mathrm{P}$ in the phytolith structure might be unavailable for plants prior to desilification

234 of the phytolith structure. Co-release of P and Si was observed and the dissolution of the 235 phytolith could be concluded as the main factor controlling P release. The heating temperature 236 of the rice straw could affect $\mathrm{P}$ and Si releases by intensifying the removal of occluded organic matter or crystallizing the silica surface of the phytolith. The maximum values of soluble P and Si observed from 500 till $700^{\circ} \mathrm{C}$ recommended that the pretreatment of the rice straw at this temperature range is optimal in serving as available P and Si for crops and soils.

240 As it is still unclear to what extent organic-P can be transformed to inorganic $\mathrm{P}$ accompanying 241 with heat treatment of the rice straw, this process and its relation to P-release will be considered in future works.

\section{Acknowledgements}

244 This research was funded by the Vietnam National Foundation for Science \& Technology 245 Development (Project 105.09-2015.01).

\section{References}

247 Agarie, S., Agata, W., Uchida, H., Kubota, F., Kaufman, P.B., 1996. Function of silica bodies 248 in the epidermal system of rice (Oryza sativa L.): testing the window hypothesis. Journal $249 \quad$ of Experimental Botany 47, 655 - 660. 
Andreae, M.O., Merlet, P., 2001. Emission of trace gases and aerosols from biomass burning. Global Biogeochemical Cycles 15, 955-966.

Bijay, S., Shan, Y.H., Johnson-Beebout, S.E., Yadvinder, S., Buresh, R.J., 2008. Chapter 3 Crop Residue Management for Lowland Rice-Based Cropping Systems in Asia, Advances in Agronomy. Academic Press, pp. 117-199.

Botha, T., 2013. A tale of two neglected systems-structure and function of the thin- and thick-walled sieve tubes in monocotyledonous leaves. Frontiers in Plant Science 4.

Dobermann, A., Fairhurst, T., 2000. Rice. Nutrient disorders and management, Handbook series. Potash and Phosphate, Singapore.

Dove, P.M., Crerar, D.A., 1990. Kinetics of quartz dissolution in electrolyte solutions using a hydrothermal mixed flow reactor. Geochim. Cosmochim. Acta 54, 955-969.

Fraysse, F., Pokrovsky, O.S., Schott, J., Meunier, J.-D., 2009. Surface chemistry and reactivity of plant phytoliths in aqueous solutions. Chemical Geology 258, 197-206.

Friese, K.I., Cichy, S.B., Wolters, F.E., Botcharnikov, R.E., 2013. Analysis of tomographic mineralogical data using YaDiV-Overview and practical case study. Comp. Geosci. 56, 92-103.

Islam, M.T., Sarwar, A.K.M.G., Begum, H.H., Ito, T., 2009. Epidermal features of rice leaf CV. BRRI Dhan29. Bangladesh Journal of Plant Taxonomy 16, 4.

Jeschke, W.D., Kirkby, E.A., Peuke, A.D., Pate, J.S., Hartung, W., 1997. Effects of P deficiency on assimilation and transport of nitrate and phosphate in intact plants of castor bean (Ricinus communis L.). Journal of Experimental Botany 48, 75-91.

Kordatos, K., Gavela, S., Ntziouni, A., Pistiolas, K.N., Kyritsi, A., Kasselouri-Rigopoulou, V., 2008. Synthesis of highly siliceous ZSM-5 zeolite using silica from rice husk ash. Microporous and Mesoporous Materials 115, 189-196. 
274 Marone, F.M., R; Modregger, P; Fife, J; Pinzer, B; Thüring, T; Mader, K; Mikuljan, G; Isenegger, A; Stampanoni, M 2010. Present and Future X-ray Tomographic Microscopy at TOMCAT., 10th International Conference on X-Ray Microscopy, Chicago, Illinois, (USA), 15 August 2010 - 20 August 2010, 116-119.

Nguyen, N.M., Dultz, S., Guggenberger, G., 2014. Effects of pretreatment and solution chemistry on solubility of rice-straw phytoliths. Journal of Plant Nutrition and Soil Science 177, 349-359.

Nguyen, N.M., Dultz, S., Picardal, F., Bui, T.K.A., Pham, Q.V., Schieber, J., 2015. Release of potassium accompanying the dissolution of rice straw phytolith. Chemosphere 119, 371376.

Parr, J.F., Sullivan, L.A., 2005. Soil carbon sequestration in phytoliths. Soil Biol. Biochem. 37, 117-124.

Schachtman, D.P., Reid, R.J., Ayling, S.M., 1998. Phosphorus uptake by plants: from soil to cell. Plant Physiology 2, 447-453.

Seyfferth, A.L., Kocar, B.D., Lee, J.A., Fendorf, S., 2013. Seasonal dynamics of dissolved silicon in a rice cropping system after straw incorporation. Geochimica et Cosmochimica Acta 123, 120-133.

Wickramasinghe, D.B., Rowell, D.L., 2006. The release of silicon from amorphous silica and rice straw in Sri Lankan soils. Biol Fertil Soils 42, 231-240.

Wilding, L.P., Hallmark, C.T., Smeck, N.E., 1979. Dissolution and Stability of Biogenic Opal1. Soil Sci. Soc. Am. J. 43, 800-802.

295 Yamaji, N., Mitatni, N., Ma, J.F., 2008. A Transporter Regulating Silicon Distribution in Rice Shoots. The Plant Cell 20, 1381-1389. 
297 Yamanaka, S., Takeda, H., Komatsubara, S., Ito, F., Usami, H., Togawa, E., Yoshino, K., 298 2009. Structures and physiological functions of silica bodies in the epidermis of rice 299 plants. Applied Physics Letters 95, 1-3.

300 Zhuravlev, L.T., 2000. The surface chemistry of amorphous silica. Zhuravlev model. Colloids 301 and Surfaces A: Physicochemical and Engineering Aspects 173, 1-38. 


\section{Table caption}

304 Table 1. Specific surface area (SSA), chemical composition of the rice straw and its phytolith 305 ash samples obtained from 300 to $1000^{\circ} \mathrm{C}$ ashing temperatures.

306

\section{Figure captions}

308 Figure 1. 3D images of the phytolith's silicaceous structure (a) and it is embedded by organic 309 matter (b)

310 Figure 2. SEM images of a leaf fragment in treated rice-straw samples: $400^{\circ} \mathrm{C}$ (a), $700^{\circ} \mathrm{C}$ (b)

311 Figure 3. XRD patterns (a) and IR spectra (b) of rice-straw samples treated at different

\section{2 temperatures}

313 Figure 4. Release of Si (a) and P (b) from rice straw samples treated at $400^{\circ} \mathrm{C}, 700^{\circ} \mathrm{C}$ and

$3141000^{\circ} \mathrm{C}$ in a time sequence up to $6 \mathrm{~d}$. Data points represent mean values with standard 315 deviations for 3 replicates. Error bars might be smaller than the symbol size.

316 Figure 5. Solubility dependence of Si and P on treatment temperature. Data points represent

317 mean values with standard deviations for 3 replicates. Error bars are smaller than the symbol 318 size.

319 Figure 6. Correlation between soluble Si and $\mathrm{P}$ in the supernatant of $400^{\circ} \mathrm{C}-, 7^{\circ} \mathrm{C}-$, and $3201000^{\circ} \mathrm{C}$-treated samples in the kinetic experiments. Where not visible, error bars are smaller 321 than the symbol size.

322 Figure 7. Illustration of temperature effect on P and Si co-release from rice straw derived 323 phytolith via changing occluded organic matter content, surface area and crystallization 324 degree. 